\title{
Innovation based on value co-creation: An alternative for Brazilian wine?
}

\author{
Martiele Cortes Borges ${ }^{1}$, Jéssica Moreira Maia Souto ${ }^{1}$, Athos Ribeiro da Silva ${ }^{2}$, Marcos Vinícius Araujo ${ }^{3}$, \\ and Daniela Callegaro de Menezes ${ }^{4}$ \\ ${ }^{1}$ Master's student of Agribusiness, Federal University of Rio Grande do Sul-Av. Bento Gonçalves, 7712, Brazil \\ ${ }^{2}$ Institutional Scientific Initiation Scholar (PIBIC) at Federal University of Rio Grande do Sul, Rua Washington Luiz, \\ 855, Centro Histórico, Brazil \\ ${ }^{3}$ Master's student of Agribusiness, Federal University of Rio Grande do Sul, Av. Bento Gonçalves, 7712, Brazil \\ ${ }^{4}$ Professor at Federal University of Rio Grande do Sul, Rua Washington Luiz, 855, Centro Histórico, Brazil
}

\begin{abstract}
The Brazilian wine industry has been facing obstacles such as competition and high tax rates. Innovation is an alternative towards this scenario being it a major factor for any company's survival and growth in the market. Besides this, technological advances and access to information provide consumers with a larger number of choices and knowledge for an informed decision making. Despite differentiation efforts consumers did not obtain satisfaction. Customer interaction provides another way to generate innovation from its involvement in the production process (co-creation of value). The research was held in an awarded winery located in Bento Gonçalves (Brazil) with the objective of understanding how the process of value co-creation between Brazilian award-winning wineries and consumers influences innovation generation. It is an exploratory and qualitative study collected through in-depth interviews with a semi-structured script. The winery identifies beneficial effects in the production process resulting from interactions because it narrows the bond with the consumer creating a better understanding of the consumers as well as develop a more tailored offer regarding value. The innovations generated based on co-creation can be taken as an alternative to imposed barriers in the current Brazilian wine sector.
\end{abstract}

\section{Introduction}

Seeking to create innovation and greater market acceptance, the wineries in Serra Gaucha have invested in infrastructure to deliver a different experience as opposed to the ones in shops and supermarkets in general. The wineries organize tastings in their properties with the support of wine tourism conducted by tour guides who show the consumer the production method and explain about essential techniques so that the consumers can have a better understanding of the wine. Also, some wineries began to offer other services such as courses, picnics and the grape harvest in which the consumer participates in the process in the vineyard. These wineries seek to approach customers in their process through experiences, not only the direct consumption of the beverage.

In this new context in which the experiences are fundamental to the development of a relationship between consumer and winery a co-creation four-element model arises. This model was named DART [1], (Dialogue, Access, Risk assessment, and Transparency). The continuous dialogue between both parties is necessary for a joined cocriation to happen. Furthermore, access is considered the access the client has to the product through an experience. Risk assessment is related to the consumer's requests for more information regarding product risks; on the other hand, the consumer's also take up more using responsibility. There must be transparency in the shared information to have trust between client and winery [2].

Understanding the flow of information is necessary to manage the productive chain, due to comprehending the final consumers and how relevant this experience is may result in a good future relationship. Moreover, it is important to understand how the wineries perceive the same relationship as opposed to the consumers to verify if the companies' intentions are indeed being attained as well as their clients'.

Given that the wineries of the Vale dos Vinhedos, Brazil's largest wine producing region needs to seek innovative solutions to compete with foreign fine wines - especially Chilean ones. As well as creating closer ties with its end consumer providing a different consumption experience this study proposes the question: How does value co-creation between the Winery and its consumers influence innovation generation?

This paper initially presents innovation and co-creation of value literature followed by the method used to develop the study. Further along the discussion and results and conclusions.

\section{Innovation}

Innovation has been a trending theme for the past few years this is due to it becoming a question of survival to many enterprises. According to [3], companies that do 
not innovate die. The reason behind it is that innovation is associated with competitive advantage. Because of economic growth, new businesses are created and with them new ideas. In this sense, innovation causes rupture of perfect competition [4] as companies that innovate are different from the ones that do not. Therefore, established companies have more difficulty, since they need to be always looking for innovation to continue in the market. On the contrary, companies wishing to enter the market find in innovation an opportunity to do so [5].

For many entrepreneurs, innovation is synonymous with creativity; this confusion can bring harm to businesses since it can be counterproductive to invest in creativity without considering other important aspects of innovation. [6]. Innovation can be perceived as "the implementation of a product (good or service) new or significantly improved, or a process, or a new marketing method, or yet a new organizational method in business practices, workplace organization or external relations [7]. This way innovation can be understood as an invention that has been brought to the [8].

There are four types of innovation: product (when a change occurs in the goods/ services' potential). Process (when you change the way to produce or distribute), organizational (when change is in business practices, workplace organization or external relations of the company). And marketing (when change is in the product's design and packaging, in product promotion and placement, and establishing methods of prices of goods and services) [7]. On the degree of novelty involved, it can be said that innovation is incremental, when significant improvements are implemented or radical, when there is a concept rupture [5]. For the degree to be perceived, it is necessary to know what is the object of comparison, as it can be considered within the firm, market-level or even worldwide [7].

Innovation requires change, directly associated with the idea of the uncertainty of the results involving investment. It is the product of the overflow of knowledge, requiring the use of new knowledge or the new use of existing knowledge and searching for performance improvement through competitive advantage [7]. For these changes to occur, knowledge and resources do not need to be within the company's limits. Open innovation adds the thought of sharing ideas generation involving other stakeholders, thus having access to innovation that would not be possible within the enterprise.

Open innovation believes in a different logic about the sources and uses of ideas. This approach understands that valuable ideas can arise within and outside the company, thus differentiating the closed innovation logic [8]. Table 1 shows the main contrasts between the two approaches:

The biggest barrier that companies need to overcome to an open innovation approach is the fear of sharing with other groups; the fear of losing their trade secrets and patents. Entrepreneurs should realize that they cannot endure the structure of their organizations and all existing capabilities to generate and implement new ideas, be them ideas, tools, knowledge or others.

The principles of closed innovation (Table 1) are based on natural resources the company has, on the assumption that it has sufficient conditions to generate new ideas and innovation developments from that. That is, the company
Table 1. Closed and Open Innovation Contrasts.

\begin{tabular}{|c|c|}
\hline Closed Innovation & Open Innovation \\
\hline $\begin{array}{l}\text { Most of the smart people } \\
\text { in our field work for us. }\end{array}$ & $\begin{array}{l}\text { Not all of the smart people } \\
\text { work for us, so we must find } \\
\text { and tap into the knowledge } \\
\text { and expertise of bright indi- } \\
\text { viduals outside our company }\end{array}$ \\
\hline $\begin{array}{l}\text { To profit from R\&D, we } \\
\text { must discover, develop } \\
\text { and deliver results }\end{array}$ & $\begin{array}{l}\text { External R\&D can create } \\
\text { significant value; internal } \\
\text { R\&D is needed to claim } \\
\text { some portion of that value }\end{array}$ \\
\hline $\begin{array}{l}\text { If we discover it, we will } \\
\text { get it to market first }\end{array}$ & $\begin{array}{l}\text { We do not have to originate } \\
\text { the research in order to profit } \\
\text { from it }\end{array}$ \\
\hline $\begin{array}{l}\text { If we are the first to } \\
\text { commercialize it we will } \\
\text { win }\end{array}$ & $\begin{array}{l}\text { Building a better business } \\
\text { model is better than getting } \\
\text { to the market first }\end{array}$ \\
\hline $\begin{array}{l}\text { If we create the most } \\
\text { and the best ideas in the } \\
\text { industry, we will win }\end{array}$ & $\begin{array}{l}\text { If we make the use of } \\
\text { internal and external ideas } \\
\text { we will win }\end{array}$ \\
\hline $\begin{array}{l}\text { We should control our } \\
\text { intellectual property (IP) } \\
\text { so that our competitors } \\
\text { do not profit from our } \\
\text { ideas }\end{array}$ & $\begin{array}{l}\text { We should profit from others' } \\
\text { use of our IP, and we should } \\
\text { buy others' IP whenever it } \\
\text { advances our own business } \\
\text { model }\end{array}$ \\
\hline
\end{tabular}

has people responsible for all the necessary steps for innovation to be launched, being it necessary, in addition to human resources, financial resources and structure for research development. Companies working this way are concerned with trade secrets, so that other businesses cannot benefit from all investments they have made to achieve innovation.

Furthermore, the company that first launches an innovation in a given market tends to get advantages over its competitors in this market. Closed innovation only has internal resources and may need a lot of investment; on the other hand, those who can develop great ideas and protect using patents can use the results for a determined time.

However, open innovation (Table 1), has principles that go beyond the boundaries of the firm. In this concept, the resources are not necessarily within the company that is developing the innovation, and it does not pose a problem because relying on outside resources is part of the development of this innovation. Emerging research needs investment, so the alternative is to share and develop it cooperatively so that everyone can get their results.

Companies working with open innovation can rely on their suppliers, customers, competitors and other stakeholders to develop, for example, better-suited systems to all users facilitating the process. The companies can also develop deals that are more aligned with consumers' interests based on the shared information. The focus of this type of innovation is not the secret keeping, but the best possible use of the idea, be it a company plan or from the outside limits. Unlike closed innovation, patents take a different direction, in which third parties may use a particular company's patents to generate revenue, besides the purchasing and selling of patents, always keeping the company's business model best interests in mind. 
As a way to gain competitive advantage, innovation has been the alternative for the Brazilian wine industry, which seeks to be established in the domestic market in competition with Chilean and Argentinean wines. Ten percent of the Brazilian population is considered rich and a survey was conducted with this population sample. Results show that the consumer does not perceive a significant difference in the Brazilian red wine compared to Chileans and Argentineans on a sensory aspect [9]. Therefore, this study indicates that the technical barriers are overcome, but for the national wine to be valued in the domestic market, marketing initiatives are needed. These initiatives have the intention of bringing the consumer of the product offered closer, thus, knowing these people and providing new features to meet their needs have become an alternative to the competitive wine market.

The Brazilian wine industry has adhered to the adoption of innovations in processes and products, which has been globally recognized through awards in contests that some wineries have acquired in recent years [10]. When considering the competition of domestic and foreign products in the internal market due to the problems faced in the industry, we see the need to seek alternatives to overcome these barriers. Strategy is responsible for generating differential which is based on market dynamics. Innovation is an essential factor to achieve this differential in the market [10]. Thus, in the Gaucho wine sector, the search for innovation is increasingly present because in addition to overcoming their competitors the wineries also seek to reach the gaucho public, even though these consumers do not yet value the product once they cannot realize its real value [9].

Innovations can be generated in various ways in business, to [11] incremental innovations occur more or less continuously, from a combination of demand pressure, sociocultural factors, technological opportunities and the professional career. Because it is not the result of a deliberate research, this type of innovation is part of the business process, so that ideas arise from daily work. On the other hand, radical innovation is discontinuous and requires deliberate research, which can boost technological advance, but nevertheless requires investments [10].

In the Gaucho wine scenario, radical innovations can become the most sophisticated alternative, because as [12], the launch of a new product (for example), may take from 1.5 to 9 years. Therefore, the sector should search for incremental innovations, as improvements suggested by users can generate innovation [11]. Thus, because it is a product whose dimensions evaluated for choice may involve intrinsic aspects (feelings) and extrinsic ("persuasive advertising") [9], the wine needs to be presented to its consumers in a way that emphasizes the dimensions they valued. Consequently, it is essential to understand more about this consumer, involving them in the process so that interactions can generate innovations with a value that is created together between them and the winery.

\section{Co-creation and the DART model}

With the changes in the approach of how value is created, and accepting the logic that presents the customer as a co-creator of unique experiences the DART model is discussed and introduces its four elements: dialogue, access, risk assessment and transparency [1].
The way that interactions occur between consumers and firms during the creation and delivery of services is essential for the existence of co-creation as the DART model. Co-creation value happens when at least one of the four elements is present in this relationship.

Dialogue means interactivity and propensity for action on both sides (both company and consumer). In addition to knowledge exchange [13] and the conversation between the two parties. It is the understanding of all the factors involved in this relationship, as the recognition of the emotional, cultural and social aspects involved in this experience. For there to be dialogue and excellent communication between the involved, there should be focused on issues that interest both parties [14]; it is necessary that meetings occur and follow rules (explicit or not) to maintain order and productivity of interactions [1]. This assumption is critical for the individual to have the opportunity to inject his vision of creating value process [13].

Access: Consumers want access to experiences, not necessarily have the ownership of the products. It is necessary to detach the idea of access to the concept of property. Access starts with the availability of tools and information needed for an experience to occur [1]. Moreover, there must be access to knowledge and expertise for individuals to build their experience [13].

Risk assessment: the likelihood of consumer harm. Entrepreneurs believe that companies can assess and better manage the risks of co-creation, so the question arises: can the firm unilaterally make risk management in co-creation? Besides, could the consumer assume the responsibilities of the risks involved in this process? Thus, risk assessment relates to co-assuming the responsibilities for decisions making during the process and the result [14]. Consumers demand more information about value co-creation risks. However, they take on more responsibility to deal with the risks involved [13].

Transparency: "the information about the products, technologies, and business systems become more affordable, creating new levels of transparency, therefore, becoming more desirable" [14]. Transparency is a way to give the consumer the necessary access to information but also involves the opening of customer information for firms to perform the activities satisfactorily. It is a two-way street. Traditionally companies have information benefits over the users; that must not occur in the value co-creation [1]. Transparency is a way to facilitate dialogue and the interactions between the parties involved in the co-creation process. It also enables a greater engagement of consumers in the process. Transparency of information is essential to the process of interaction as it creates trust between company and customer [13].

Some combinations of the blocks were also commented from this model [2]:

Access and transparency: It is possible to make better and more informed decisions through giving access to the consumer and being transparent in sharing information. 


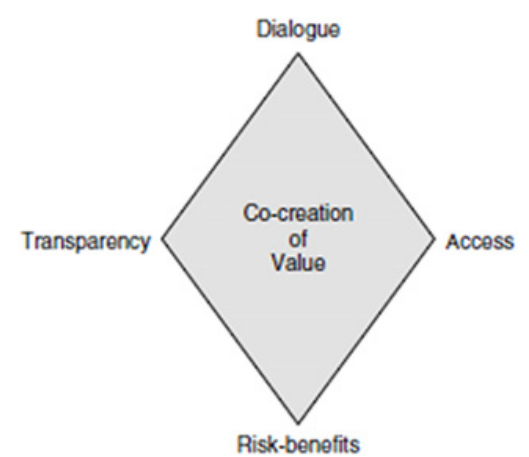

Figure 1. DART Model. Source: PRAHALAD; RAMASWAMY (2004a, p.9).

Dialogue and Risk Assessment: This combination improves the ability to develop public and private debates about policy choices.

Access and dialogue: Combined, these premises facilitate the development of thematic communities.

Transparency and Risk Assessment: This combination improves the ability to create trust.

\section{Methods}

This study is characterized as qualitative with exploratory purpose. Its primary objective is to better understand the research problem for further research [15]. This kind of the investigation is done when the subject is poorly explored, making it difficult to formulate hypotheses about a given fact [15].

Thus, we sought this goal through a case study approach, in an attempt to understand some aspects of an in-depth research problem [16]. A case study is an exhaustive study of one or more subjects to know it in depth and detail [15]. Research questions with the word "how" can be answered with the use of case studies, because these issues require operational links that are uncovered over time [17]. Moreover, this type of research is employed in contemporary cases, where no one can control the behavior of the variables involved [17].

In January 2016, an in-depth interview with the winemaker responsible for the management of the winery was carried out, from a semi-structured script. Data collection from interviews is an efficient technique to get information about human behavior [15]. Furthermore, the use of unstructured script gives greater flexibility to the researcher [15]. The interview was recorded and transcribed with permission of the interviewee to ensure the reliability of the data. Also, secondary data about the winery was sought to improve knowledge about its activities.

To analyze the data collected a comparison of the interview responses to the literature on the subject was carried out. The DART model (dialogue, access, risk assessment, and transparency) was used as the basis for construction of the instrument collection and data analysis. Regarding this model, the authors state that the presence of just one of its elements is enough for co-creation of value to existing.

\section{Results and discussion}

Winery A began its activities in 1974, seeking to maintain the traditions brought by Italian immigrants to the region in the XIX century. It is currently part of the Route of Historic Canteens, located in the city of Bento Gonçalves (Brazil).

The marketing of their products is carried out through various channels, mainly in the states of Santa Catarina, the Rio Grande do Sul, Rio de Janeiro and São Paulo. Sales to the final consumer are made mostly through telemarketing, accounting for about $50 \%$ of sales. This service is a channel where the consumer has proximity to its attendant, with personalized service.

\section{Innovation and Co-creation of value in Winery $A$}

The winery seeks to maintain open contact with its customers, identifying its telemarketing as the focal point for information exchange and interaction. The company realizes that this is where consumers give feedback about the products, and the service received, in addition to performing their purchases. Thus, promoting communication and sales through telemarketing was an innovation in marketing [7] which has brought many benefits to the winery, since about $50 \%$ of its products are sold through that channel.

Also, telemarketing attendants are responsible for customer service in the physical store, seeking to generate a relationship and leading the consumer to understand this relationship as a bond of friendship. The winery mentions that there are instances when customers invite attendants to their personal events. The winery realizes that its customers feel valued with these interactions, actively participating in the winery processes and bringing up new ideas.

Access

Currently, the winery has a museum, the Ecomuseum of Wine Culture, which aims to show consumers the wine tradition in Serra Gaucha, besides offering public exhibitions and events. The winery offers training to waiters, aid for tastings and other services that consumers may desire.

The actions are taken on Facebook (wine matching tips, recipes, news about wine), as well as the actions were taken in bars and restaurants (such as prize draws to visit the winery), contributed to consumers to keep in contact with the winery. All these actions are part of a new way to communicate with customers, as the wineries seek deeper interaction with stakeholders. Thus, Winery A believes that using digital platforms and providing resources so that interest groups acquire more knowledge to participate and bring new ideas with potential to generate innovations is necessary for the relationship to become profitable for both sides.

\section{Risk Assessment}

The winery understands that there is no risk in its engagement with its consumers. On the contrary, it believes that this relationship provides excellent results. The company seeks to meet as many demands as possible from consumers, however, it is not feasible to take them all into consideration, as far as the viability of the business goes [8]. presents open innovation as a characteristic in which the smartest people will not always be part of the 
company but the company may know that they may count on them. Thus, it is important to realize that in this case, the participation of consumers and suppliers is critical to the business of Winery A, for without trust these relations could not guarantee the service quality and sales' channels used. Knowing the risks and understanding them is a necessary step in this process of co-creation to generate innovation.

On the other hand, marketing across multiple channels arises a conflict between retailers and the winery, where the consumer can buy at lower prices. Retailers consider that there is unfair competition, whereas the winery believes that it does not compete with a shopkeeper who sells its products in other cities. To resolve this conflict discussion between the parties and negotiated prices are necessary. However, in some cases, one or more marketing channels might have to be given up in certain locations.

\section{Transparency}

The winery believes that its customers feel safe in sharing information, being open to provide it without difficulty. Also, this security is due to the trust in their relationship with the winery because customers realize that there is a bilateral exchange of information.

With a transparent relationship, consumers come to trust the winery and engagement increases. Thus, consumers can participate more in the process of generating ideas, and the winery can innovate responding to consumer demands from the very beginning.

The winery seeks loyalty, believing that it can improve their innovation generation process. The client finds greater satisfaction to be present not only in the purchase step but also in generating ideas.

\section{Conclusions}

DART model [1] shows that if at least one of the four elements is present, the company becomes a co-creator. Thus, from the analysis of these items' behavior in the winery, it was revealed that there is an active value cocreation process with consumers.

The process of generating ideas is where consumers are indispensable because the winery makes them part of this step and values what they request. Co-creation between the winery and consumers creates new ideas continuously; fostering innovation and making consumers feel like they are part of the change.

\section{References}

[1] V. Prahalad and C. K. Ramaswamy, The Future of Competition: Co-Creating Unique Value with Customers. Boston: Harvard Business School Press, 2004
[2] C. K. Prahalad and V. Ramaswamy, "Co-creating unique value with customers," Strategy. Leadersh., vol. 32, no. 3, pp. 4-9, 2004

[3] H. Chesbrough, "Business model innovation: Opportunities and barriers," Long Range Plann., vol. 43, no. 2-3, pp. 354-363, 2010

[4] J. A. Schumpeter, Capitalism, Socialismo e Democracia. Rio de Janeiro: Fundo de Cultura, 1961

[5] J. BESSANT, J.; TIDD, Inovação e empreendedorismo. Porto Alegre: Bookman, 2009

[6] F. T. De Bes and P. Kotler, A Bíblia da Inovação: princípios fundamentais para levar a cultura da inovação contínua às organizações. São Paulo: Texto Editores Ltda., 2011

[7] OCDE, Manual de Oslo, Terceira. OCDE e Eurostat, 2005

[8] H. Chesbrough, Inovação Aberta: Como criar $e$ lucrar com a tecnologia. Porto Alegre: Bookman, 2012

[9] J. P. P. Révillion, S. H. Flôres, E. de O. Wilk, M. S. Badejo, G. D. Mercali, L. M. Gandolfi, M. J. L. Alles, R. F. Mariot, S. U. de Campos, A. Sampaio, and A. M. Romero, "Qualidade sensorial de vinhos tintos finos do Rio Grande do Sul comparados aos importados da Argentina e Chile," Food Sci. Technol., vol. 27, no. 1, pp. 177-180, 2007

[10] A. C. M. Padilha, L. S. Severo, N. de A. Delgado, and T. N. da Silva, "Inovação Tecnológica Em Indústrias Competitivas Do Agronegócio: Uma Análise Na Cooperativa Vinícola Aurora Ltda. Rs," Estud. Debate, vol. 17, no. 1, pp. 91-109, 2010

[11] C. Freeman and C. Perez, "Structural crises of adjustment, business cycles and investment behaviour," Technical Change and Economic Theory. pp. 38-66, 1988

[12] P. Hayashi-Junior, "Uso De Recursos Na Criação De Vinhos Ícones E a Cocriação De Valor,” p. 199, 2011

[13] V. Ramaswamy, "Co-creating Experiences with Customers?: New Paradigm of Value Creation," TMTC J. Manag., pp. 6-14, 2005

[14] C. K. Prahalad and V. Ramaswamy, "Co-creation experiences: The next practice in value creation," $J$. Interact. Mark., vol. 18, no. 3, pp. 5-14, 2004

[15] A. C. Gil, Métodos e Técnicas de Pesquisa Social, 6. São Paulo: Editora Atlas S.A., 2008

[16] J. Bell, Projeto de Pesquisa: guia para pesquisadores iniciantes em educação, saúde e ciências sociais., 4. Porto Alegre: ARTMED EDITORA S.A., 2008

[17] R. K. Yin, Estudo de Caso. Planejamento e Métodos., Quarta. São Paulo: ARTMED EDITORA S.A., 2010 